Volume 19, 2020

\title{
BIBLIOGRAPHIC REVIEW OF THE FLIPPED ClassRoOM MODEL IN HigH SCHOOL: A LOOK FROM THE TECHNOLOGICAL TOOLS
}

\begin{tabular}{|c|c|c|}
\hline Lina M. Pastes Urbano* & $\begin{array}{l}\text { Telematics Department, Faculty of } \\
\text { Electronic Engineering and Tele- } \\
\text { communications, Universidad del } \\
\text { Cauca, Popayán, Colombia. }\end{array}$ & linampastesu@gmail.com \\
\hline Hamil S. Terán & $\begin{array}{l}\text { Telematics Department, Faculty of } \\
\text { Electronic Engineering and Tele- } \\
\text { communications, Universidad del } \\
\text { Cauca, Popayán, Colombia. }\end{array}$ & hamil@unicauca.edu.co \\
\hline Fabinton Sotelo Gómez & $\begin{array}{l}\text { Telematics Department, Faculty of } \\
\text { Electronic Engineering and Tele- } \\
\text { communications, Universidad del } \\
\text { Cauca, Popayán, Colombia. }\end{array}$ & fabinton.sotelo@unicauca.ed \\
\hline Mario F. Solarte & $\begin{array}{l}\text { Telematics Department, Faculty of } \\
\text { Electronic Engineering and Tele- } \\
\text { communications, Universidad del } \\
\text { Cauca, Popayán, Colombia. }\end{array}$ & msolarte@unicauca.edu.co \\
\hline Carlos J. Sepulveda & $\begin{array}{l}\text { Telematics Department, Faculty of } \\
\text { Electronic Engineering and Tele- } \\
\text { communications, Universidad del } \\
\text { Cauca, Popayán, Colombia. }\end{array}$ & sepul0392@,unicauca.edu.co \\
\hline Juan M. López Meza & $\begin{array}{l}\text { Telematics Department, Faculty of } \\
\text { Electronic Engineering and Tele- } \\
\text { communications, Universidad del } \\
\text { Cauca, Popayán, Colombia. }\end{array}$ & lmjuan@unicauca.edu.co \\
\hline
\end{tabular}

*Corresponding author

\footnotetext{
Accepting Editor Justin Filippou | Received: March 15, 2020 | Revised: May 24, June 10, July 4, July 7, 2020 | Accepted: July 13, 2020.

Cite as: Pastes Urbano, L. M., Terán, H. S., Sotelo Gómez, F., Solarte, M. F., Sepulveda, C. J., \& López Meza, J. M. (2020). Bibliographic review of the flipped classroom model in high school: A look from the technological tools. Journal of Information Technology Education: Research, 19, 451-474. https://doi.org/10.28945/4605

(CC BY-NC 4.0) This article is licensed to you under a Creative Commons Attribution-NonCommercial 4.0 International License. When you copy and redistribute this paper in full or in part, you need to provide proper attribution to it to ensure that others can later locate this work (and to ensure that others do not accuse you of plagiarism). You may (and we encourage you to) adapt, remix, transform, and build upon the material for any non-commercial purposes. This license does not permit you to use this material for commercial purposes.
} 


\section{ABSTRACT}

Aim/Purpose

Background

Methodology

Contribution

Findings

Impact on Society

Future Research

Keywords
The purpose is a bibliographic review that seeks to offer a clearer vision of the impact of technological tools on the implementation of the flipped classroom model.

This document reviews the flipped classroom and secondary education literature to analyze what technological tools are used to implement this model in secondary education settings and their impact on students.

For the review, an analysis of 61 articles found in SCOPUS and WOS was carried out, processed with a scientometric tool, where the implementation of the inverted classroom model in high school is evident, and, according to these, an in-depth analysis was carried out on which tools are most used and in which contexts they are applied.

This document offers new researchers a more unobstructed view of what type of technological tools have been implemented in the flipped classroom model in the context of high school and how students perceive them.

This review analyzes the following aspects:

- Analysis of the leading countries where the flipped classroom model is applied in secondary education.

- Analysis of the subjects where the flipped classroom model has been implemented.

- It offers an analysis of the most used technological tools and in which contexts they are applied (online or offline).

This document helps new researchers make a conscious decision about the type of tool to implement to support the flipped classroom model and shows the importance of developing technological tools that are not limited by the use of the internet so that they can reach a more significant number of people.

Carry out research that focuses on applications that support low connectivity contexts, in order to improve the implementation of the flipped classroom model.

flipped classroom, high school, technology platforms

\section{INTRODUCTION}

At present, the speed with which technology advances is increasing and has permeated almost all areas of daily life has helped solve problems and meet the needs that society currently faces (Méndez, 2012), producing innovation and constant change in all social fields. The area of education is no exception (Adell \& Castañeda, 2012; Cabero Almenara, 2015), and the use of information and communication technologies (ICTs) has been implemented gradually and made available to educational tools that contribute to improving the participation and implementation of different learning models (Sotelo et al., 2015). Also, in recent years, new ways of teaching have been sought to improve and deal with the problems of traditional educational models. (Jiugen et al., 2014) and go beyond a simple transmission of knowledge (Adell \& Castañeda, 2012; Sosa \& Manzuoli, 2019), seeking to provide more interactive classes and broader educational resources. From these perspectives, new learning strategies that make use of ICTs are booming (Alkoudmani \& Elkalmi, 2015; Kostaris et al., 2017; 
Méndez, 2012); these include b-Learning, e-Learning, MOOCS and the flipped classroom model, which has been gaining strength in recent decades (Akçayır \& Akçayır, 2018; Lage et al., 2000). In the flipped classroom model, videos, readings, or any other academic activity that students can do independently at home are used, and the classroom is transformed into a meeting point where practical activities are carried out, doubts are resolved, and consolidated knowledge. Studies have shown that the flipped classroom model has proved to be more effective compared to traditional teaching models and has positively impacted student academic results (Bishop \& Verleger, 2013). This is reflected in studies such as Dawood et al. (2017), Y. Li \& Daher (2016), McBride (2015), and Triantafyllou et al. (2015); they demonstrated that when applying the flipped classroom model, better results were obtained in the evaluations in comparison with the courses of the traditional class, in addition to improving motivation and promoting self-directed and self-regulated learning in students. (Akçayır \& Akçayır, 2018).

Although the definition of the flipped classroom model does not require the use of technology (Abeysekera \& Dawson, 2015; Kim et al., 2014), many authors see this as an opportunity to improve the learning process (L. Cheng et al., 2019; Lo et al., 2017), since it allows us to minimize the time and geographical restrictions that are commonly presented (Soares \& Lopes, 2016). However, the literature does not show how the use of technological tools and platforms impact the flipped classroom model. Therefore, this literature review aims to provide potential researchers with condensed information on the tools that have been used to implement the flipped classroom model in the context of secondary education. For this purpose, the tools found in the review are described, their characteristics, the context in which they are applied, and how students and teachers use and perceive them.

\section{THEORETICAL BACKGROUND}

\section{FLIPPED CLASSROOM}

The flipped classroom model is a teaching model whose main objective is that the student assumes an active role during the learning process. This model reverses the processes and roles that occur in traditional teaching models (Berenguer-Albaladejo., 2016; Lage et al., 2000); that is, it uses time outside the classroom to teach the lessons through multimedia tools, and class time is used to solve doubts, carry out practices, open discussion forums and reinforce learning; through interactive methods of collaborative work and problem-based learning (Martínez Olvera et al., 2014).

This learning model reverses the proposed model in Bloom's taxonomy (Conklin, 2005), which divides the learning process into cognitive processes, some of a lower order and others of a higher order from the level of complexity (Churches, 2009). In the lower level are processes such as the acquisition and understanding of knowledge, while in the higher-order processes are the processes that have to do with the use of knowledge, analysis, synthesis, and evaluation (Berenguer-Albaladejo, 2016). Under this premise, the flipped classroom model proposes that lower-order cognitive processes take place outside the classroom; that is to say that the students study the theoretical concepts for themselves through the various tools that the teacher makes available, such as videos or podcasts recorded by the teacher or other people, and class time is used to answer questions related to the material provided and deepen the issues (Soares \& Lopes, 2016; Triantafyllou et al., 2015; Ureña et al., 2007).

Based on the concepts proposed by the flipped classroom model, several studies have been carried out that aim to show the results obtained when using the model in the academic context. In Pereira and Figueiredo (2010) a model with three lines of action is proposed. The first is to involve students in learning tasks using a technological platform, which allows the integration of the main concepts of the topic to be discussed. The second line of action involves discussions on topics relevant to the course, using forums available at the platform. The third line of work tries that each student shows an individual reflection on the course; however, a quantitative analysis is not presented that allows verifying the efficiency of the platform in this proposed model. 
Another model is found in Peres et al. (2017) and in Zhao and Gao (2010), this consists of six levels or stages. In the first stage, knowledge is presented, which includes behaviors that underline the importance of remembering ideas. In the second stage, the teacher delivers the subject to the student; In the third stage, the use of technological tools is proposed to promote the teaching in students. As a fourth stage, a verification method is proposed where the acquired knowledge is evaluated. In a fifth stage, the development of synthesis is proposed where each student can unite the parts of a context and obtain a complete and different point of view of the evaluation of critical learning. In the final stage, an assessment is proposed for the student to have comprehensive, analytical, and creative abilities on their own. However, the investigations do not show the use of any specialized platform for the implementation of this type of model; only the use of repositories is proposed. This avoids the existence of a two-way communication mechanism with the student and the teacher.

In Wang (2016), a "Chinese Learning” system is used, which seeks to encourage students and read course materials before class to obtain prior knowledge. It allows teachers to change their role from informants to instructors, and students can make full use of the developed system. This type of methodology aims to show a positive effect on student learning performance, facilitating the application of the flipped classroom model. Although it is a system developed at the University of Tamkang, in China, it is not evident if the system is capable of operating in low connectivity environments.

In other investigations such as Y. Li et al. (2018), an adaptation of the concept of teaching CDIO (Conceive - Design - Implement - Operate) (Takemata et al., 2013) is proposed to introduce a model of teaching projects, cases, and learning of practices, through the use of a flipped classroom using Massive Open Online Courses (MOOC) (Andone \& Mihaescu, 2018). This flipped classroom model has three stages: In the first stage, they propose the construction of a MOOC; In a second stage, the advantages of blended learning are adapted for the acquisition of knowledge by teachers, with the aim of technological modifications; As a final stage, the teacher focuses on changing the class model in real environments, where the teacher does not use class time. Still, each student learns independently at home and arrives at the classroom with doubts and solving exercises to strengthen their knowledge. Changing the learning status of students from passive to active to increase communication between teachers and students; however, the use of MOOC is restricted to online environments, which excludes the population that does not have an internet connection.

In Overmyer (2015), the use of the flipped classroom is studied in an algebra course, based on a teaching model that consists of taking advantage of the use of technologies and time at home, of interacting with the teacher solving doubts or exercises. This study seeks to compare and make an analysis of traditional teaching methods through a test or evaluation of both approaches. The article proposes the use of the Blackboard platform to manage the resources required for the home, this to have a record of the students; however, the study suggests that the use of this type of private application generates costs overruns for the academic year.

It is possible to conclude that all the flipped classroom models shown above are based on the premise of creating interactive and active student-centered learning strategies. For this, the flipped classroom model inverts what is typically done in the traditional model providing significant advantages in academic achievement. Additionally, in most studies, they do not detail the characteristics of the platforms used, nor is the possibility of introducing them in contexts with low internet connectivity evident.

\section{PuRPose OF THE STUdY}

The flipped classroom model has proven to be a trend that arouses academic interest in recent years (Akçayır \& Akçayır, 2018; Bishop \& Verleger, 2013); this, added to recent technological advances, have made this an attractive field of research. Many studies have shown how the implementation of the flipped classroom model backed by technological tools and platforms has improved learning outcomes and practices compared to traditional teaching. But, so far, no study focuses on reviewing the 
technical means used to implement the model and how they impact the teaching and learning process. This review is intended to provide researchers with a more unobstructed view of how technology tools are used to influence the flipped classroom model. This research will allow making more conscious decisions about the type of tool that will be used for the implementation of the model. This review will detail the current state of knowledge around the classroom model in secondary education. To achieve this purpose, we identify all the articles that investigate the flipped classroom model in the WOS and Scopus databases as of September 30, 2019. To answer the following two questions:

- Identify the technological tools used in the implementation of the flipped classroom model.

- What are the characteristics of these tools, and in which contexts are they used (online or offline)?

\section{METHOD}

The proposed method is based on Linares-Espinós et al. (2018). It proposes four phases to carry out a systematic review. The first, identification, consists of finding the articles according to a topic, carried out in different article search bases; a second phase called screening consists of filtering to exclude equal articles from different bases; in the third phase consists of filtering methods in order to reduce the number of articles and focus on a more specific topic; finally, a last phase called included allows obtaining the majority of articles according to the specific topic chosen for the review.

For this literature review, a bibliometric review of the flipped classroom model was carried out using the ScientoPy tool (Ruiz-Rosero et al., 2019). As a search strategy systematic searches were carried out in online databases from 1999 to September 30, 2019. This period was considered adequate since the term of flipped classroom arose at the end of the nineties (Lage et al., 2000). The search in the database of SCOPUS and WOS (web of science) was carried out using the following search string "(Flipped classroom) AND (Inverted learning)". For its subsequent analysis, with the ScientoPy scientometric tool with the following criteria.

- Repeated studies within the databases were eliminated.

- To do this, all the files downloaded from the databases are grouped together and duplicate files within this pool are removed.

- The keywords were selected within the context of the flipped classroom in high school.

- Using the ScientoPy tool, the first 500 most repeated words within the articles found were selected, and from them, the ones that are framed within the context of a flipped classroom in high school were selected. The studies that were chosen must be framed within the contexts of high school.

After searching the databases, pre-processing with ScientoPy was performed to eliminate duplicate elements; of the 12,684 original samples, duplicates were identified by title and identical authors; studies published in WOS were maintained and those that were in Scopus were subtracted, which yielded the number of 5400 studies. Table 1 shows a summary of this process.

Subsequently, the first 500 keywords of the studies were identified, and a pre-selection of those containing keywords related to the context of high school was made; 10 articles that are related to the keyword colleges and universities were also included since their content was related to the topic to be dealt with in this review. In total, 61 reviews were found under the theme of flipped classroom framed within the high school as can be seen in Table 2 and Figure 1. 
Table 1: Preprocessing process.

\begin{tabular}{|c|c|c|}
\hline Information & Number & Percentage \\
\hline Total documents found & 12684 & $100 \%$ \\
\hline Number of documents WOS & 2557 & $20.2 \%$ \\
\hline Number of Scopus documents & 10127 & $79.8 \%$ \\
\hline Duplicate documents & 7284 & $57.4 \%$ \\
\hline Number of Documents after pre-processing & 5400 & $100 \%$ \\
\hline Number of documents WOS & 2316 & $42.9 \%$ \\
\hline Number of Scopus documents & 3084 & $57.1 \%$ \\
\hline
\end{tabular}

Table 2: Selected Studies by keyword.

\begin{tabular}{|lc|c|c|c|c|c|}
\hline & Keywords & Total & AGR & ADY & PDLY & H-Index \\
\hline 1 & secondary education & 14 & 0.0 & 3.5 & 50.0 & 5 \\
\hline 2 & colleges and universities & 10 & -1.5 & 1.0 & 20.0 & 1 \\
\hline 3 & High School/Introductory Chemistry & 6 & -0.5 & 0.0 & 0.0 & 4 \\
\hline 4 & K-12 education & 5 & -1.0 & 0.0 & 0.0 & 3 \\
\hline 5 & High School & 4 & 0.0 & 1.5 & 75.0 & 1 \\
\hline 6 & Middle School & 4 & 0.5 & 1.5 & 75.0 & 1 \\
\hline 7 & High school students & 3 & 0.0 & 0.5 & 33.3 & 2 \\
\hline 8 & colleges & 2 & 0.0 & 1.0 & 100.0 & 0 \\
\hline 9 & secondary mathematics & 2 & 0.0 & 0.5 & 50.0 & 1 \\
\hline 10 & High school education & 1 & 0.0 & 0.0 & 0.0 & 0 \\
\hline 11 & K-12 teaching & 1 & -0.5 & 0.0 & 0.0 & 0 \\
\hline 12 & Middle school science & 1 & 0.0 & 0.5 & 100.0 & 1 \\
\hline 13 & Secondary & 1 & -0.5 & 0.0 & 0.0 & 1 \\
\hline 14 & Secondary Biology & 1 & 0.0 & 0.0 & 0.0 & 1 \\
\hline 15 & Secondary School Teacher & 1 & -0.5 & 0.0 & 0.0 & 1 \\
\hline 16 & Secondary English & 1 & -0.5 & 0.0 & 0.0 & 0 \\
\hline 17 & Secondary inverted indexing & 1 & 0.5 & 0.5 & 100.0 & 0 \\
\hline 18 & Secondary school mathematics & 1 & -0.5 & 0.0 & 0.0 & 1 \\
\hline 19 & & 1 & -0.5 & 0.0 & 0.0 & 1 \\
\hline 20 & secondary school students & 1 & 0.0 & 0.5 & 100.0 & 1 \\
\hline 21 & education k12 & 0 & 0.0 & 0.0 & 0 & 0 \\
\hline 22 & lower secondary & 0 & 0.0 & 0.0 & 0 & 0 \\
\hline 23 & upper secondary & & & & & \\
\hline & & 0.0 & 0.0 & 0 & 0 \\
\hline
\end{tabular}




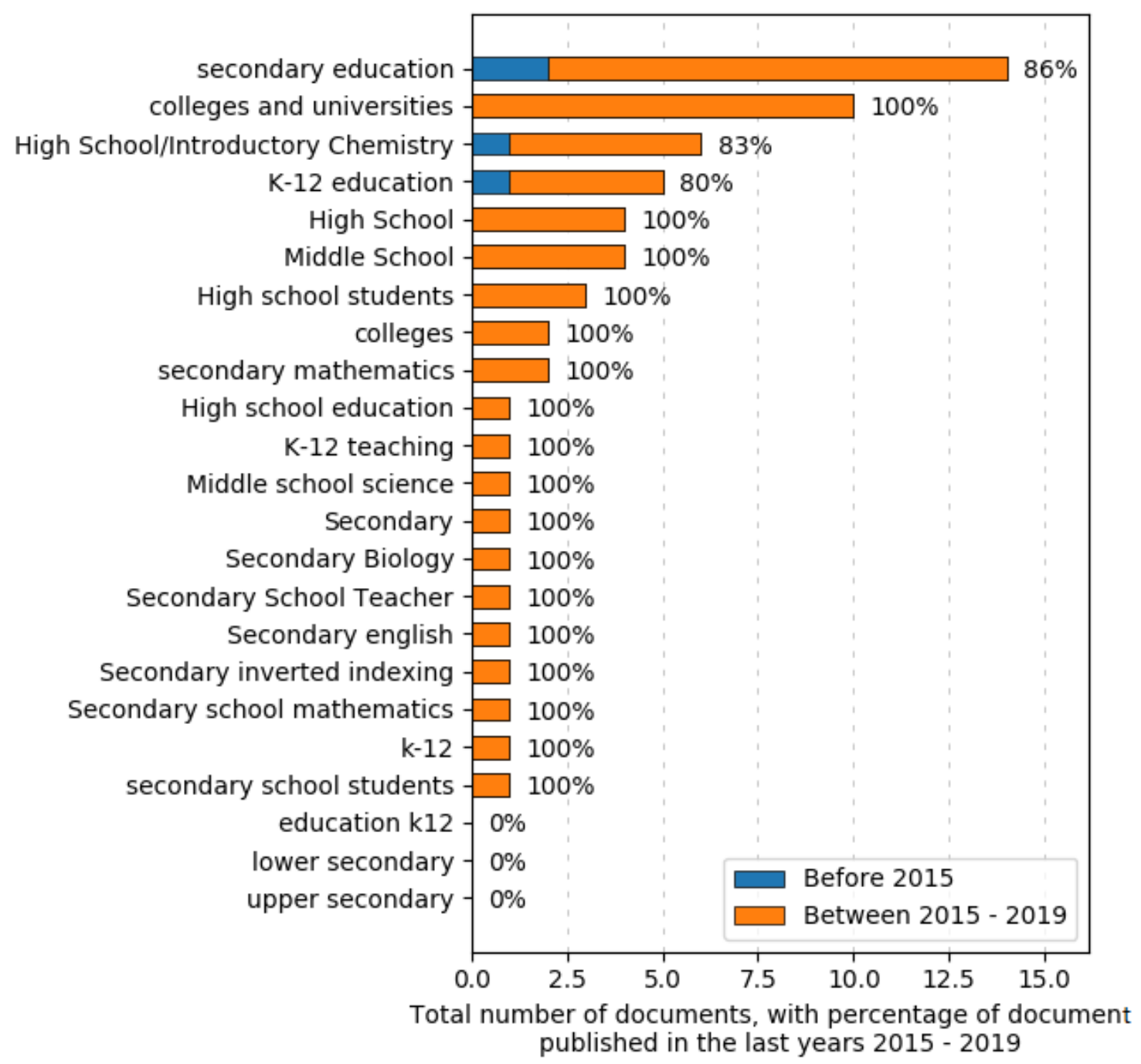

Figure 1: Studies found in recent years (The percentages shown in the figures correspond to the number of articles published between the years 2015 and 2019).

\section{RESULTS}

Studies found about a flipped classroom in the context of high school are mostly a recent issue. From the analysis in Figure 1, it can be seen that $93.4 \%$ of the selected articles have been published in the last five years. The first article found is titled "Using Lean in the Flipped Classroom for At Risk Students" and dates from 2013. This article shows the need for the traditional educational system to continually improve, and how the use of educational technology can help achieve this task. The article recounts an example of discussion of what a high school did to improve educational practice using continuous improvement and educational technology through the flipped classroom model, which resulted in an improvement in class dynamics and positively impacted student performance (Flumerfelt \& Green, 2013). For the year 2019, five studies were found, among them G. Cheng and $\mathrm{Ng}$ (2019) where it is indicated that secondary school students have a positive attitude towards the flipped classroom model since it allows them to learn at their own pace, promoting interactions of class between the teacher and the students. In Almasseri and AlHojailan (2019) a study was conducted with eighth-grade students to determine the effect of the flipped classroom approach 
based on the cognitive theory of multimedia learning and its relationship with the academic achievements of the students, which led to positive results in terms of academic achievement. Likewise, most of the studies found show that the implementation of the flipped classroom model generates advantages over the traditional learning model (Kong, 2014, 2015; Lo \& Hew, 2018).

\section{COUNTRY ANALYSIS}

A list was generated with the ten countries that have the most considerable number associated studies within the general context of flipped classroom (Figure 2), to contrast with the countries where more studies have been carried out within the context of high school (Figure 3), where it can be observed that the first four countries that have published within the context of high school are among the top ten of the countries with the highest number of publications within the general context of the flipped classroom model. The country with the most significant number of publications is China with a total of 21 studies which correspond to $34.4 \%$ of the reviews found for high school; followed by the United States with $19.6 \%$; Spain with $9.8 \%$ and Taiwan with $6.5 \%$ of the selected studies.

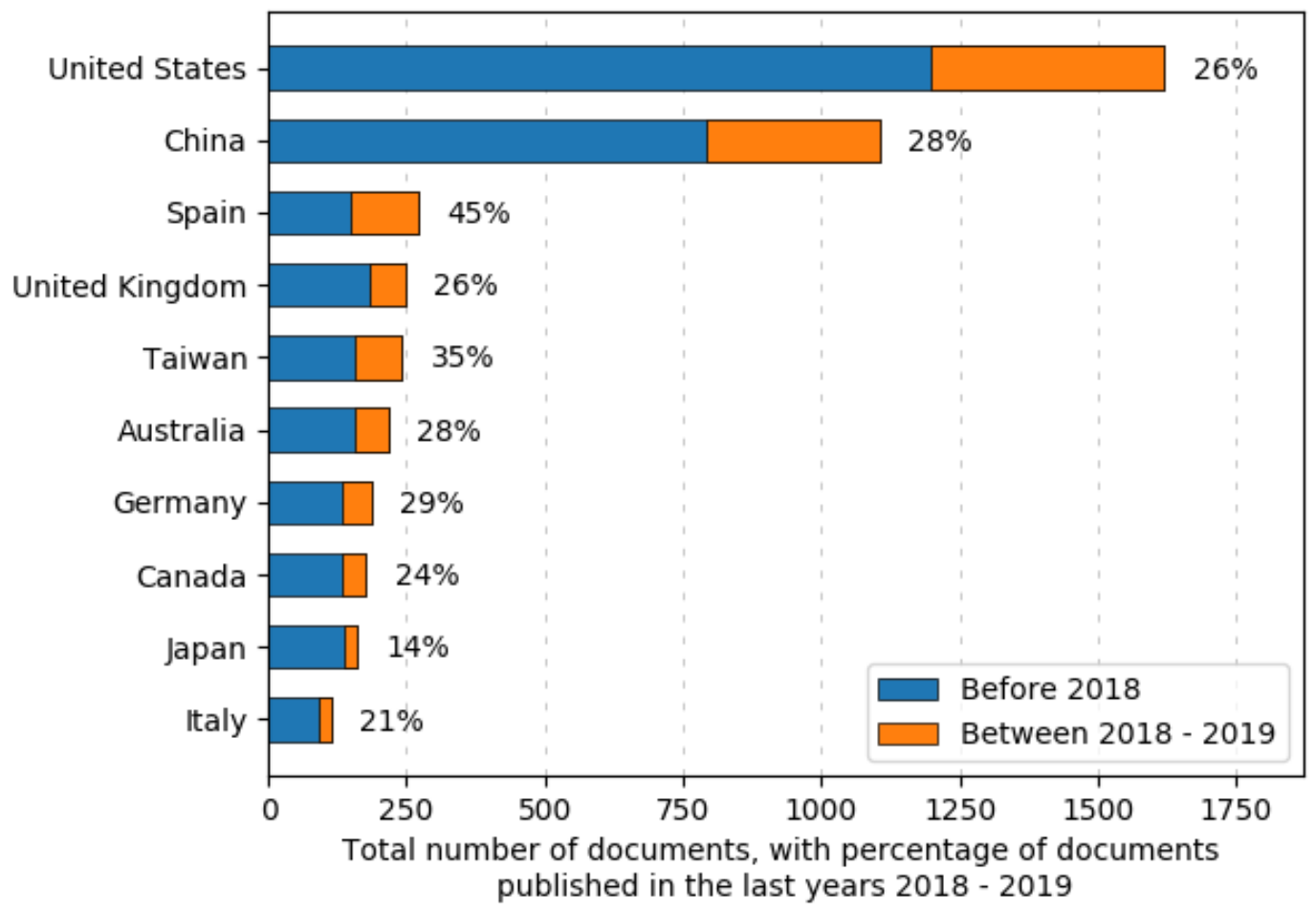

Figure 2: Analysis by countries in the context of the flipped classroom. (The percentages shown in the figures correspond to the number of articles published between the years 2015 and 2019). 


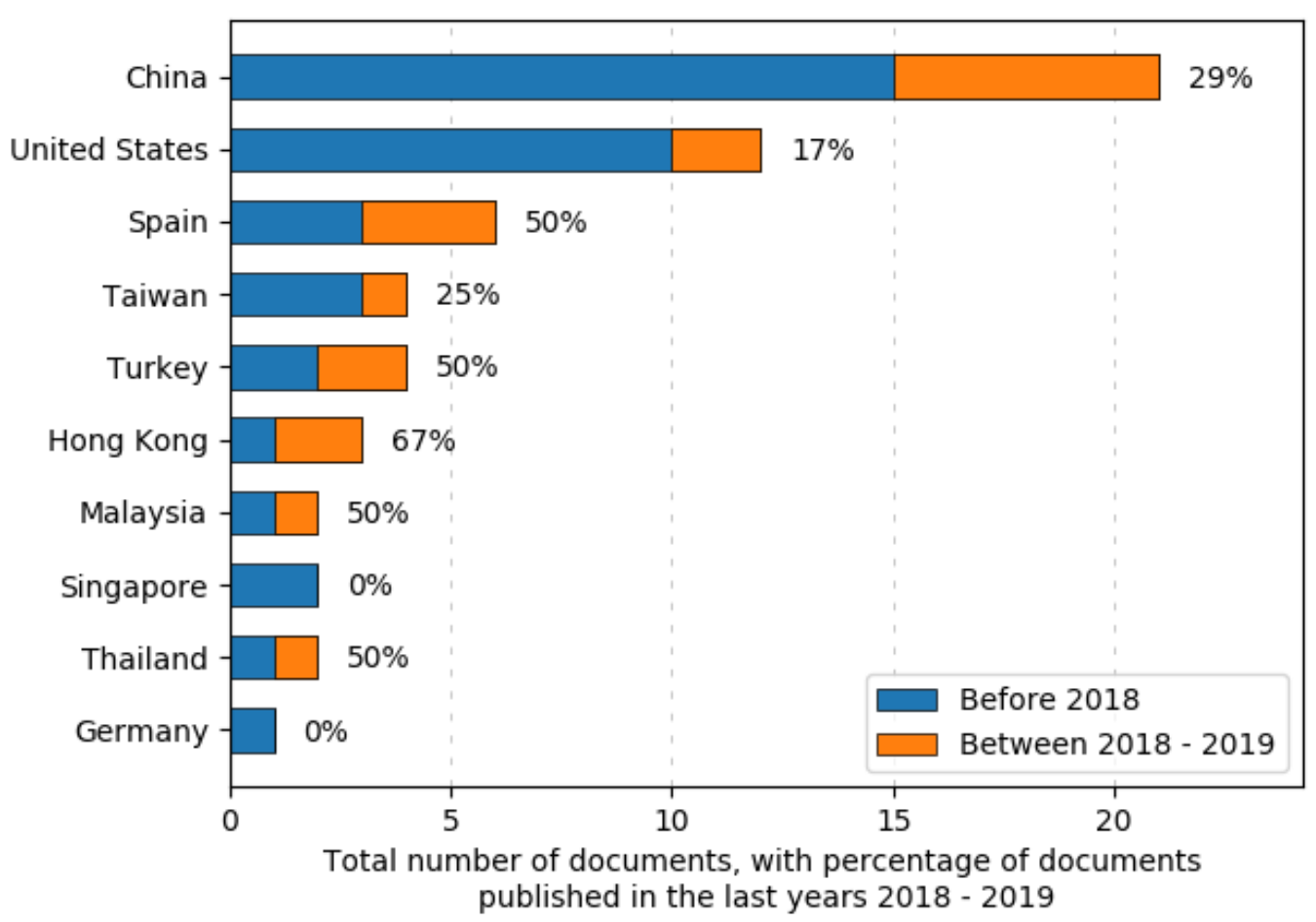

Figure 3: Analysis by countries in the context of high school. (The percentages shown in the figures correspond to the number of articles published between the years 2015 and 2019).

Within the context of high school, publications from a total of 18 different countries (Table 3) are identified. These countries are classified based on the human development index (HDI); which is a summary measure of human development that measures the progress made by a country in three basic dimensions of human development (enjoy a long and healthy life, access to education, and decent living standards) and are classified as very high, high, medium, and low. According to the ranking published by UNDP (2018), at the very top, it is the United States, Norway, Australia, Spain, Argentina, Taiwan, Hong Kong, Malaysia, Singapore, Greece, Germany, Italy, and Saudi Arabia. In the high classification is Turkey, Thailand, Brazil, Mexico, and China. In the medium and low ranking, no study was found. From this information, it is possible to deduce that the countries in which human development is highest are those that are in the continuous search for mechanisms that allow changes to be made that improve the traditional educational process. It is also possible to infer that the absence of studies and applications of the flipped classroom model in high school environments in countries with medium or low HDI is because they do not have the technological conditions for its implementation (Dawood et al., 2017; Kashada et al., 2017).

Table 3: List of countries with publications in the context of high school.

\begin{tabular}{|c|c|c|c|}
\hline Country & Total & Country & Total \\
\hline China & 21 & Argentina & 1 \\
\hline United States & 12 & Australia & 1 \\
\hline Spain & 6 & Brazil & 1 \\
\hline Taiwan & 4 & Germany & 1 \\
\hline Turkey & 4 & Greece & 1 \\
\hline Hong Kong & 3 & Italy & 1 \\
\hline Malaysia & 2 & Mexico & 1 \\
\hline Singapore & 2 & Norway & 1 \\
\hline Thailand & 2 & Saudi Arabia & 1 \\
\hline
\end{tabular}




\section{STUDY MATTER ANALYSIS}

The flipped classroom model has been implemented in different contexts, and diverse case studies have been carried out to prove its effectiveness (Davies et al., 2013; Fautch, 2015; Mason et al., 2013). In this section, the keywords of the articles selected for this study were analyzed since most authors include their research topic in the keywords of the document; this to obtain the subjects or academic areas that have been studied the most; Figure 4 summarizes the results found. In the context of high school, different case studies have been evaluated in various academic subjects, which proves that the flipped classroom model is capable of transforming the learning model of almost any area. This model has been implemented in traditional areas such as mathematics (Bhagat et al., 2016; Lo \& Hew, 2018), where promising results have been obtained by reversing traditional learning processes, as can be seen in the study conducted by (Bhagat et al., 2016) which aims to show the effectiveness of the flipped classroom model in math learning in high school. For this, a trigonometry course was taught and the results were compared between a control group and another where the flipped classroom model was implemented. This resulted in the experimental group having a better performance at the end of the course, which suggests that the flipped classroom environment improves learning achievement. This learning model encourages motivation in math students. Another area where the flipped classroom model has been successfully implemented is in the teaching of a foreign language (Ayçiçek \& Yanpar Yelken, 2018; Martínez-Olvera Olvera \& Esquivel-Gámez, 2018; Huang \& Hong, 2016; Yang, 2017). In this last study (Yang, 2017), it was possible to see that the flipped classroom model for learning English as a foreign language is a powerful teaching strategy when used with high school students since it promotes autonomy and motivation, which resulted in a greater understanding of the language by the students. We must also include that the inverted model has also been implemented in little known areas such as music (Palazón-Herrera, 2018), the sports dance (Y. Li, 2015), and even for the teaching of pre-laboratories, which is atypical. However, it was shown that the implementation of the inverted model making use of videos had made the learning process more stimulating (Fung, 2015).

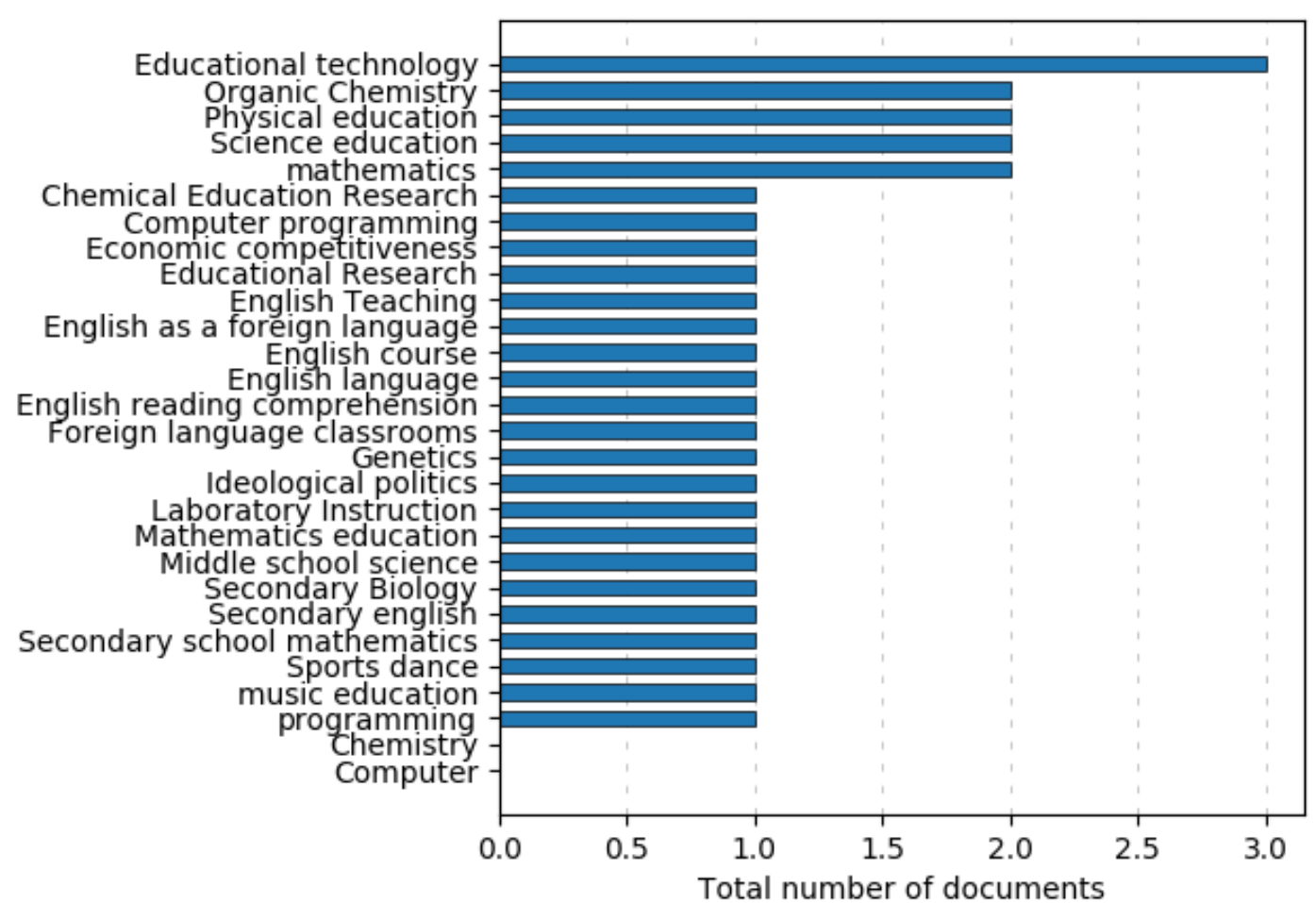

Figure 4: Analysis of the subjects where the flipped classroom has been implemented. 
To generate the graph in Figure 4, the ScientoPy tool was used to identify the keywords of the sample. To identify each of the subjects the synonyms search function was used and from this information the graph was obtained.

\section{TOOL ANALYSIS}

In this section, the technological tools used to implement or support the flipped classroom model in the context of high school were manually identified; For this analysis, we excluded seven studies from the original sample because they were not accessed.

Digital technologies represent an essential aspect of the flipped classroom methodology since they allow the teacher to produce, use, reuse, and share learning materials; They also enable students to access it, when and where it is convenient. (Soares \& Lopes, 2016). Under this premise, most of the research carried out within the context of the flipped classroom in high school makes use of technological tools to implement this model. The most used technological tools are the online learning elements that are mostly used in pre-class activities. However, some tools and platforms do not support the flipped classroom model. Below are the tools used to implement the flipped classroom environment within the context of high school. The graph (Figure 5) summarizes the most used technological tools in the context of high school.

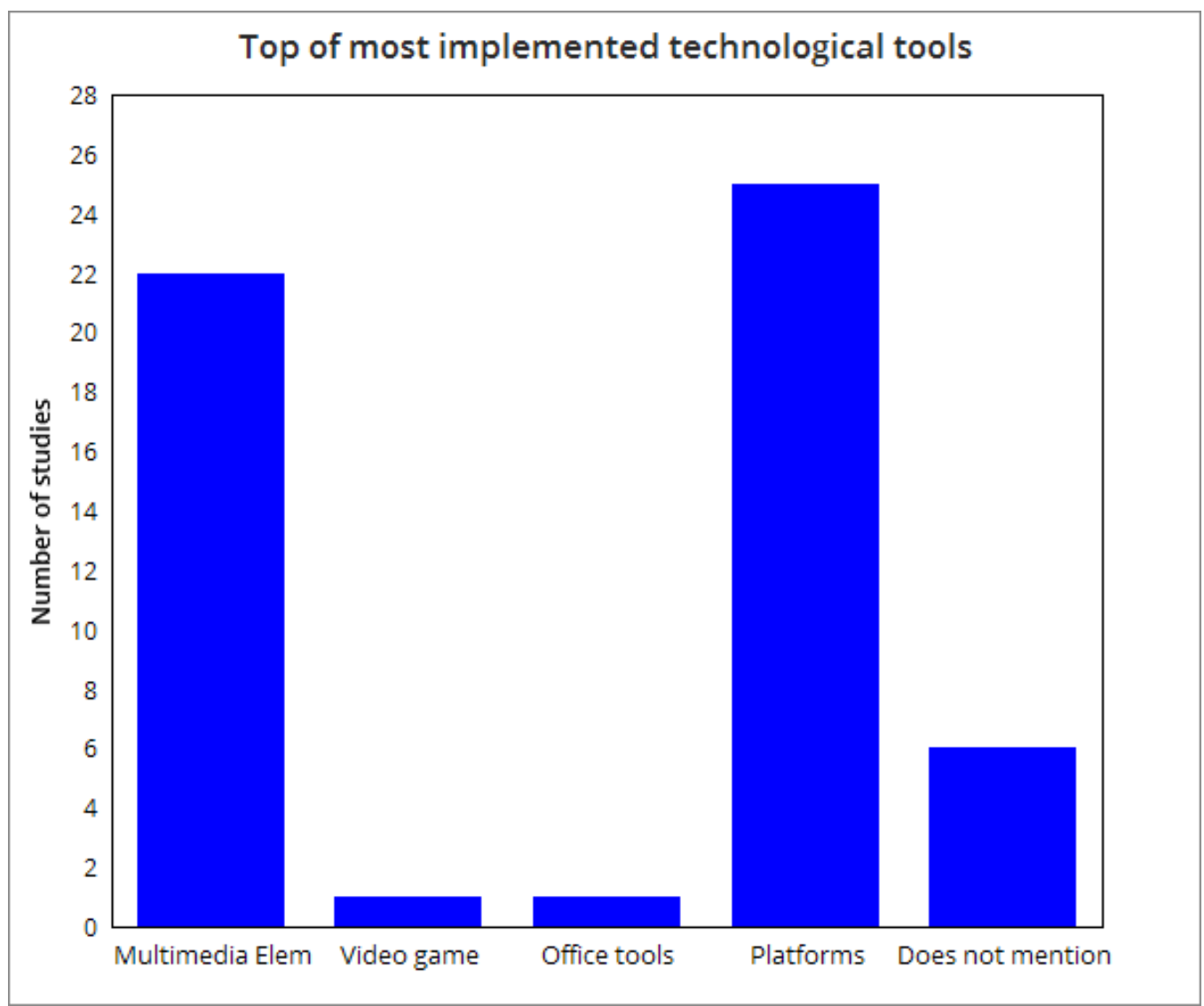

Figure 5: Top of most implemented technological tools

From the study of the articles, it was identified that 22 mention only the use of multimedia elements for the implementation of the flipped classroom model, which corresponds to $43.7 \%$ of the studies analyzed. 25 studies refer to the use of platforms for content management, which corresponds to $46.3 \%$ of the studies surveyed. The use of office tools such as Google-Docs was also mentioned in a 
study which corresponds to $1.8 \%$ as well as the use of commercial video games for the implementation of the flipped classroom model. Finally, $11.1 \%$ of the studies do not mention any implementation tools. The technological tools found are detailed below.

\section{Multimedia elements}

In most of the selected studies, videos, presentations, or micro-conferences are used to instruct students about the contents that will be studied in the class. It was found that the use of this type of content had a positive impact on students, since they are able to see, pause, and rewind the material, which promotes students to learn at their own pace and promotes self-directed learning and self-regulated (de Araujo et al., 2017; Kashada et al., 2017; Z. Li, et al., 2017; Shao et al., 2016). As evidence of it, Flumerfelt and Green (2013) conducted a study where, with the help of a screen capture software for the creation of videos, the learning elements were created and subsequently delivered to the students so that they can be accessed before class. This implementation showed advantages compared to the traditional model since it allows students to review the content, as necessary, what was perceived by the students as a more pleasant task that they could control. In Yan and Cheng (2017) a study is presented where online videos and questionnaires were used as pre-class activities for teaching programming in a secondary school, which yielded positive results regarding the implementation of the model and showed that the flipped classroom could improve acceptance of the students of the programming. In Palazón and Giráldez (2018) online videos were used, which were accessed through QR codes associated with videos on YouTube. The study resulted in the group that implemented the flipped classroom model using this method obtaining better results in contrast to those in which more traditional resources were used. In Fung (2015) first-person videos recorded with go-pro were used for a pre-laboratory. It was concluded that with this element, the student could observe the scientific experiment before class, as if he were in the laboratory classroom, improving the understanding of scientific experiments. Finally, another number of studies also use videos and presentations to implement the flipped classroom model, showing similar results to the previous ones (Ayçiçek, \& Yanpar Yelken, 2018; Hodgson et al., 2017; Huang \& Hong, 2016; Y. Li, 2015; Lo et al., 2018; Zheng, 2016).

\section{Video game}

In Ye et al. (2018) a study is shown that uses commercial video games as learning elements before class for students in a physics group. The video game "Ballance" (published by Cyparade in 2004) was used; in this game, players must ensure that a ball they control (wood, rock, or paper, depending on the player's choice) reaches their destination within a limited time frame. The players must consider mass, gravity, and inertia when moving balls along the tracks. Also used was "Angry Birds" in which players must shoot birds from trenches to attack pigs that steal eggs. This game used knowledge such as oblique, horizontal, projectiles, collisions, and inertia. This study resulted in the use of these video games having the potential to improve student motivation and help them develop a better understanding of pre-class concepts, as they encouraged exploration and experimentation activity by combining based learning in games and the flipped classroom model.

\section{Online office tools}

In Kong $(2014,2015)$ Google tools such as Google-Docs were used to create collaborative discussion groups and create worksheets that allow students to work collaboratively with group members. In Almasseri \& AlHojailan (2019), Schultz et al. (2014) and Winter (2018) the Google-Forms tool is used in which teachers carry out questionnaires to evaluate the content seen by students in the class.

\section{Platforms}

Of the 25 studies that mentioned the use of platforms to manage the content delivered to students (Figure 6), Moodle stands out as the most implemented with a total of 7 reviews, followed by the Khan-Academy, Edmodo, Google-Classroom, and Ed-puzzle with two studies each. Finally, the 
OpenHPI, Google-Drive, Open-edX, Gocort, code.org, and Dropbox platforms were implemented in one study each. The following section provides a description of the technological platforms identified in the investigation.

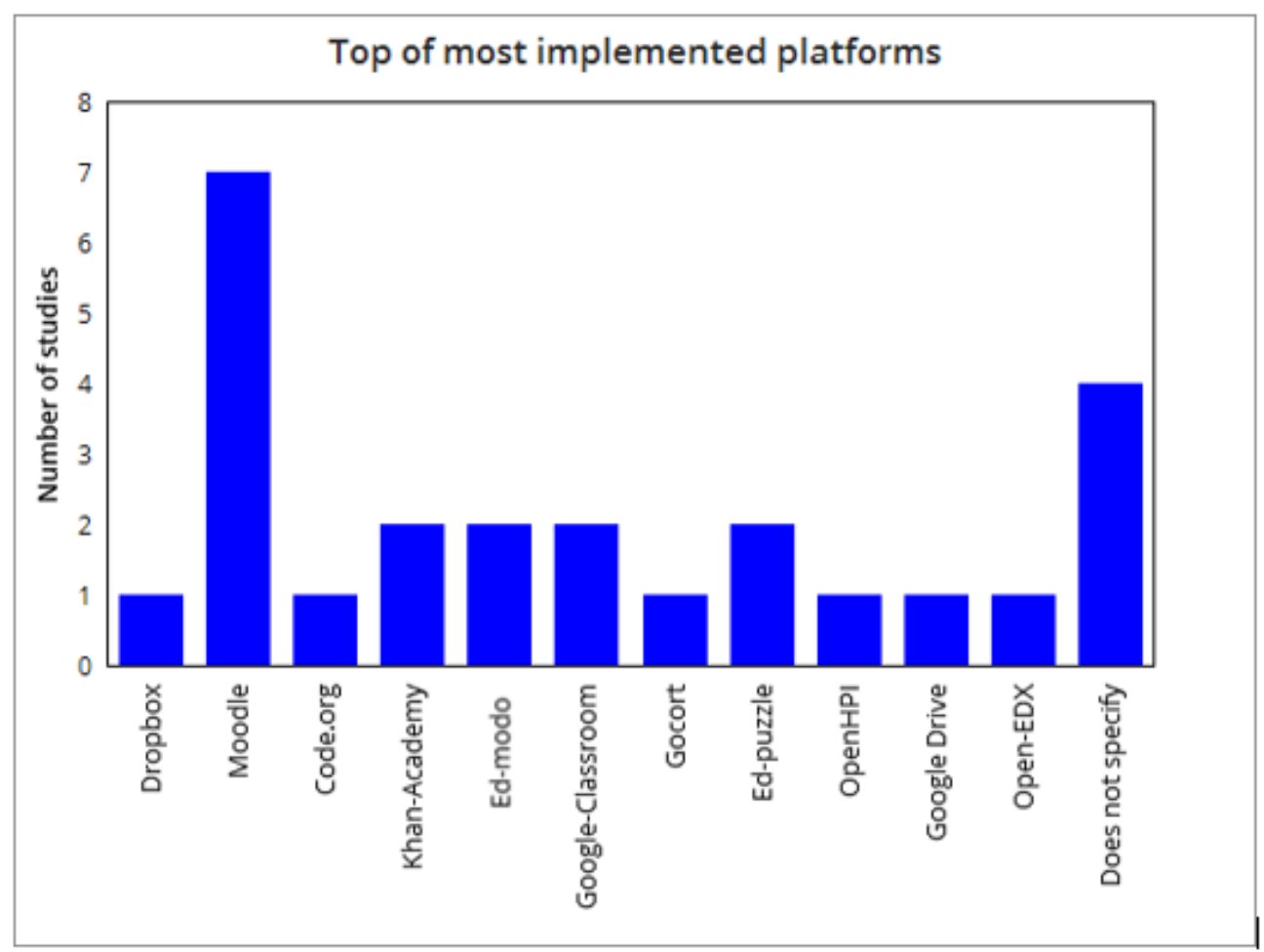

Figure 6: Platforms found in the reviewed articles

\section{PLATFORMS}

This section describes the main characteristics of the technological platforms used to implement the flipped classroom model in the context of high school.

\section{Moodle}

Moodle (https://moodle.org/?lang=en) is an open-source learning platform that allows you to create personalized and robust learning environments for teachers and students by making available a robust set of student-centered tools and collaborative learning environments.. In the study presented by Lo and Hew (2018), the Moodle platform is used so that the ninth grade students can access the content before class, in addition gamification elements such as digital points, badges, levels with a progress bar through the Moodle platform were made available, although the perception of the platform by the students is not evaluated; The results obtained by the students in the inverted class were better than those in which the model was not applied.

The studies carried out by Kostaris et al. (2017), Leo and Puzio (2016), and Slemmons et al. (2018) propose the use of the Moodle platform for the presentation of educational videos and evaluation questionnaires to the pre- class session, so that students become familiar with the concepts before the class section. The platform allows the integration of evaluations with multiple options and selection false or true evaluations that are automatically graded (Leo \& Puzio, 2016). In all these studies, the result of the model implementation also produced positive results compared to the teacher-centered models. Finally, in Martínez-Olvera and Esquivel-Gámez (2018), the Moodle platform is also used by integrating the JclicAuthor tool, which allows you to create activities simply, and enables you 
to obtain an immediate evaluation of the activities carried out. This functionality provides for the teacher to see the students' progress. All the investigations that used the Moodle platform did it in online contexts.

\section{Edmodo}

Edmodo (https://www.edmodo.com/) is a free online social network learning platform that allows one to create closed groups between students and teachers to share educational content such as messages, files, links, work calendars, as well as allow one to create tasks and manage them (Edmodo, 2008). In the investigations carried out by García et al. (2015) and Yildiz Durak, (2018) the Edmodo tool for mobile devices was used so that students can receive notifications about course activities, messages, and shared resources. It was possible to identify that the Edmodo environment is appropriate for high school students since it has a structure similar to that of Facebook which facilitates its use by students (Yildiz Durak, 2018). In both studies, the flipped classroom model managed to show improvements in levels of self-efficacy and commitment to the course.

\section{Khan Academy}

Khan Academy is a non-profit online platform, where you can upload video lessons. The objective of this platform is to allow the spread of knowledge to anyone in any location, through its repository of resources for flipped classroom (Giglio, 2014). In the studies carried out by Giglio (2014) and Hao (2016), the Khan-Academy platform and YouTube were used for a foreign language class in which PowerPoint presentations integrated with audio and video were delivered as pre-class activities. Even though the academic results were similar to those of traditional teaching methods; the flipped classroom model helps develop collaborative and social skills and promotes student motivation.

\section{Edpuzzle}

Edpuzzle is a web tool that uses videos and allows adding questionnaires within them. In Ayçiçek \& Yanpar Yelken (2018), a case study for an English class is presented to which a series of video conferences with multiple questions were delivered through the edpuzzle platform. The platform allows the teacher to observe if the student has looked at the video, as well as the number of times the student repeats the video and the answers to the questions. The study resulted in a higher degree of responsibility with the academic commitments of the class in the flipped classroom group compared whit the control group. In a survey by Evangelista et al. (2018), the inverted model was implemented to a high school physics course with the help of the edpuzzle tool since it allows us to verify if the students looked at the content of the videos. This study showed that more than $90 \%$ of the students always carried out the assigned activities. In addition, a general acceptance of the tool and the method used by the students was perceived; they stressed that the use of video conferences is a more dynamic method that saves time while studying.

\section{Gocort}

Gocort is a social network developed by private initiative that allows creating an interactive learning environment for students and teachers, with tools that will enable you to create notes about content, mind maps, questionnaires, and exercise lists. Because of its social network architecture, it is easy to use and allows students to search for content in a database that contains great content. In the study carried out Bissoli et al. (2018) this platform is used for teachers to create teaching materials for teaching "Genetics" with the flipped classroom model, demonstrating that this model brings significant advantages as long as teachers are willing to create the content.

\section{Open-edX}

Open-edX is a free mass learning software platform, which includes a learning management system (LMS) and the man-system management (CMS) course called Studio, and which provides a friendly 
interface for the instructors where they can build the course, to which different content can be linked, such as videos, HTML content, and evaluation activities. On the other hand, the LMS allows showing the contents of the courses. Students and teachers can browse the contents of the course and interact with their peers. In Martínez et al. (2015), a study, a case study was carried out to implement the flipped classroom model in a math MOOC, with the help of the Open-edX platform articulated with the ANALYZE tool, which allows analyzing the information provided by the learning platform. This tool provides a different interface for teachers and students. Students have access to information only about their activities, while teachers can access the report of the entire class and of each student who takes the course individually. This helps students to be aware of how they are progressing on the platform and improve their motivation and helps teachers keep track of the class (Martínez et al., 2015).

\section{Dropbox and Google Drive}

Dropbox and Google Drive are online multi-platform file hosting services, allowing you to store, share, and synchronize content with different users. In Rahman et al. (2018), Google Drive was used to share the material of the pre-class moment for the student to interact with the content for 5 to 10 minutes. On the other hand, in Bhagat et al. (2016), Dropbox is used to manage the pre-recorded videos, which lasted between 15 to 20 minutes. At the end of the study, the test showed that students who took the inverted class had better learning and motivation achievements.

\section{Google-Classroom}

Google-Classroom is a free online learning platform designed to implement the blended learning model. This platform allows you to manage class content online and enables you to create documents, share information, videos, spreadsheets, presentations, and work collaboratively. In Almasseri and AlHojailan (2019) a study is presented in which Google- Classroom mobile is used so that students can access and interact with the content through their smartphones. The material consisted of video tutorials, homework, and online questionnaires after each lesson. In the case study conducted by Yang (2017) Google-classroom is also used so that students of an English class can access the instructional videos before the class. In this study, it was observed that the students are receptive to this type of methodology, where $79.3 \%$ of the students carried out the pre-class activities, and $81 \%$ indicated that the invested activities encouraged the development of self-management skills.

\section{OpenHPI}

OpenHPI is a platform for MOOC courses that offers content aimed at a broad audience about the fundamentals of computer science, digital technologies, and topics related to computer science in German and English. In Grella et al. (2016) this platform was used for a high school computer course. Short videos, reading material, and questionnaires for students were published on the platform, and course participants can access the learning materials at an appropriate time and as often as necessary. The results of the analysis showed that MOOCs could support high school by providing valuable content for learning.

\section{Code.org}

Code.Org is a non-profit organization that is dedicated to expanding access to computer science in elementary and secondary schools, offering open-source resources online. In G. Cheng \& $\mathrm{Ng}$ (2019) the use of this tool for a programming course is evidenced in which it is sought to observe the opinions of the students about the flipped classroom process; instructional videos of the code.org platform were used for this purpose. The results obtained indicate that students have positive attitudes towards learning programming through the flipped classroom model, compared to traditional models, since it allows them to learn at their own pace. 
Each of the tools detailed above allowed us to implement the flipped classroom model more efficiently. Still, it is essential to note that in the studies found there is no analysis of the perception of the tools by students or teachers, only identification of the general perception of the model. But in all the studies analyzed, the results found are positive.

\section{SUMMARY}

Table 4 summarizes the characteristics that comprise the tools. The learning elements design module is featured; it allows the teacher to create a specific model for a particular class. The learning elements design module is one of the characteristics that comprise these tools. In addition to this, a gamification module is presented to encourage the student, another module presents in various applications in the assessment module, which allows you to create, view, and perform exams. Another module that is mentioned in the literature is based on the possibility of sharing information in different environments; for this review, only two platforms were found that support this module. This summary is presented below.

Table 4: Characteristics found on the platforms.

\begin{tabular}{|c|c|c|c|c|c|c|c|c|c|c|}
\hline \multirow{2}{*}{$\begin{array}{l}\text { Name of } \\
\text { Platform }\end{array}$} & \multirow{2}{*}{$\begin{array}{c}\text { Module of } \\
\text { learning } \\
\text { elements } \\
\text { design }\end{array}$} & \multirow{2}{*}{$\begin{array}{l}\text { Module of } \\
\text { Gamifica- } \\
\text { tion }\end{array}$} & \multirow{2}{*}{$\begin{array}{l}\text { Module } \\
\text { of } \\
\text { Evalua- } \\
\text { tions }\end{array}$} & \multirow{2}{*}{$\begin{array}{l}\text { Mod- } \\
\text { ule of } \\
\text { Stor- } \\
\text { age }\end{array}$} & \multicolumn{2}{|c|}{ Context } & \multirow{2}{*}{$\begin{array}{l}\text { Share } \\
\text { infor- } \\
\text { mation }\end{array}$} & \multirow{2}{*}{$\begin{array}{l}\text { Mo- } \\
\text { bile } \\
\text { App }\end{array}$} & \multirow{2}{*}{$\begin{array}{l}\text { Web } \\
\text { App }\end{array}$} & \multirow{2}{*}{ Content } \\
\hline & & & & & Online & $\begin{array}{l}\text { Of- } \\
\text { fline }\end{array}$ & & & & \\
\hline Moodle & $\mathrm{X}$ & $\mathrm{X}$ & $\mathrm{X}$ & $\mathrm{X}$ & $\mathrm{X}$ & - & - & - & $\mathrm{X}$ & $\begin{array}{l}\text { Videos, } \\
\text { PDF, Im- } \\
\text { ages, } \\
\text { HTML, } \\
\text { Links, Files }\end{array}$ \\
\hline Edmodo & - & $\mathrm{X}$ & - & $\mathrm{X}$ & $\mathrm{X}$ & - & $\mathrm{X}$ & $\mathrm{X}$ & $\mathrm{X}$ & $\begin{array}{c}\text { Files, links, } \\
\text { messages, } \\
\text { work calen- } \\
\text { dars }\end{array}$ \\
\hline $\begin{array}{c}\text { Khan Acad- } \\
\text { emy }\end{array}$ & - & $\mathrm{X}$ & - & - & $\mathrm{X}$ & - & - & $\mathrm{X}$ & $\mathrm{X}$ & Videos \\
\hline Edpuzzle & - & - & $\mathrm{X}$ & $\mathrm{X}$ & $\mathrm{X}$ & - & - & $\mathrm{X}$ & $\mathrm{X}$ & Videos \\
\hline Goconqr & $\mathrm{X}$ & & $\mathrm{X}$ & $\mathrm{X}$ & $\mathrm{X}$ & - & - & - & $\mathrm{X}$ & $\begin{array}{l}\text { Videos, } \\
\text { PDF }\end{array}$ \\
\hline Open EDX & $\mathrm{X}$ & $\mathrm{X}$ & $\mathrm{X}$ & $\mathrm{X}$ & $\mathrm{X}$ & $\mathrm{X}$ & - & - & $\mathrm{X}$ & $\begin{array}{l}\text { Videos, } \\
\text { PDF, Im- } \\
\text { ages, Links, } \\
\text { Files }\end{array}$ \\
\hline $\begin{array}{c}\text { Dropbox } \\
\text { and Google } \\
\text { Drive }\end{array}$ & - & - & $\mathrm{X}$ & $\mathrm{X}$ & $\mathrm{X}$ & - & $\mathrm{X}$ & $\mathrm{X}$ & $\mathrm{X}$ & $\begin{array}{l}\text { Videos, } \\
\text { PDF, Im- } \\
\text { ages, links, } \\
\text { Files }\end{array}$ \\
\hline
\end{tabular}




\begin{tabular}{|c|c|c|c|c|c|c|c|c|c|c|}
\hline \multirow{2}{*}{$\begin{array}{l}\text { Name of } \\
\text { Platform }\end{array}$} & \multirow{2}{*}{$\begin{array}{l}\text { Module of } \\
\text { learning } \\
\text { elements } \\
\text { design }\end{array}$} & \multirow{2}{*}{$\begin{array}{c}\text { Module of } \\
\text { Gamifica- } \\
\text { tion }\end{array}$} & \multirow{2}{*}{$\begin{array}{c}\text { Module } \\
\text { of } \\
\text { Evalua- } \\
\text { tions }\end{array}$} & \multirow{2}{*}{$\begin{array}{c}\text { Mod- } \\
\text { ule of } \\
\text { Stor- } \\
\text { age }\end{array}$} & \multicolumn{2}{|c|}{ Context } & \multirow{2}{*}{$\begin{array}{l}\text { Share } \\
\text { infor- } \\
\text { mation }\end{array}$} & \multirow{2}{*}{$\begin{array}{l}\text { Mo- } \\
\text { bile } \\
\text { App }\end{array}$} & \multirow{2}{*}{$\begin{array}{l}\text { Web } \\
\text { App }\end{array}$} & \multirow{2}{*}{ Content } \\
\hline & & & & & Online & $\begin{array}{l}\text { Of- } \\
\text { fline }\end{array}$ & & & & \\
\hline $\begin{array}{l}\text { Google- } \\
\text { Classroom }\end{array}$ & - & $\mathrm{X}$ & $\mathrm{X}$ & $\mathrm{X}$ & $\mathrm{X}$ & - & - & $\mathrm{X}$ & $\mathrm{X}$ & $\begin{array}{l}\text { Videos, } \\
\text { PDF, Im- } \\
\text { ages, Links, } \\
\text { Files }\end{array}$ \\
\hline OpenHPI & $\mathrm{X}$ & $\mathrm{X}$ & $\mathrm{X}$ & $\mathrm{X}$ & $\mathrm{X}$ & - & - & - & $\mathrm{X}$ & $\begin{array}{l}\text { Videos, } \\
\text { PDF }\end{array}$ \\
\hline Code.org & - & - & $\mathrm{X}$ & - & $\mathrm{X}$ & - & - & - & $\mathrm{X}$ & Videos \\
\hline
\end{tabular}

\section{DISCUSSION}

In this article, a literary review of the inverted classroom approach within the high school was conducted, which shows that the implementation of this learning model is a trend that has been growing in recent years and that its application in high school has brought a number of advantages compared to traditional teaching models, from a teacher-centered learning model to a student-centered one that encourages motivation and self-directed and self-regulated learning, which translates primarily into an improvement in the student's academic performance. Of the inverted implementations in the classroom, this study found that that most of the technological resources are used for the pre-class sections; it was observed that the most used technological resource is the video/conference This element stands out for its ability to pause, rewind the contents where, and when necessary, what encouraged individualized learning by students (Schultz et al., 2014). With respect to the use of tools for the management of academic content, it was observed that all the tools found were applied in contexts where Internet service was available. For the most part, these platforms were only used to deliver the content to the students, with the exception of Open-edX in which it was possible to receive comments on the work done on the platform and Edpuzzle that allowed one to observe video management metrics. The other platforms were used only to share educational content with students. This can be a problem since there is no way to verify the actions, participation, or behavior of students outside the classroom (Hodgson et al., 2017). Finally, with the help of this study, it is possible to infer that the use of technological applications in the context of high school will help teachers in their teaching process and, in the same way, will improve student learning. However, it is not possible to highlight a tool that is the most suitable to implement the model, since there is no evidence that catalogs one above the other. Therefore, work must continue on initiatives that allow technological tools to fit better the context of the flipped classroom taking into account the conditions of accessibility to technology, environments with low connectivity, and the collection of measurements that allow observing behavior of students during the learning process.

\section{CONCLUSIONS}

The conclusions found in this study are described below.

Through this bibliographic review, it was possible to corroborate the importance that ICTs have for the implementation of the flipped classroom model. It was possible to determine that multimedia elements are the preferred resources to teach the students, as well as that educational technology platforms play a crucial role in the implementation of this model, since they allow to design and present the different themes to the students, and even to carry out evaluations. Thanks to this review, it is 
possible to determine that $45.5 \%$ of the articles surveyed used this type of tool, mainly, Moodle, Khan-Academy, Ed-Modo, Google-Classroom, and Ed-puzzle due to their wide diffusion.

It was possible to identify that most of the recognized technological platforms share similar characteristics, such as the learning elements design module, the gamification, evaluation, and storage module. The combined ones allow us to have a robust platform capable of supporting the flipped classroom model. It is also important to highlight that in the analyzed studies, there is no evidence that any of these platforms have been used in offline areas or contexts, which shows that there is a technological gap for the implementation of this model in these conditions. It is also left to see the internet as a limiting factor for the implementation of this model. This is corroborated with the analysis carried out at the beginning of this article, where it was shown that none of the countries with HDI at medium and low levels had carried out studies of the implementation of this model.

We can conclude that the inverted classroom model brings advantages for the educational process, as well as the use of technology, which has the potential to improve the model of traditional classes. But until now most of the technological initiatives that have been developed to implement this model do not allow its implementation in areas with difficult internet access; therefore, it is necessary that the applications, in addition to allowing the support of this model, be able to work in low connectivity environments, so that the use of ICT and the inverted classroom model are not limited to the use of the internet.

\section{REFERENCES}

Abeysekera, L., \& Dawson, P. (2015). Motivation and cognitive load in the flipped classroom: definition, rationale and a call for research. Higher Education Research \& Development, 1-14. https://doi.org/10.1080/07294360.2014.934336

Adell, J., \& Castañeeda, L. (2012). Tecnologías emergentes, pedagogías emergentes [Emerging technologies, emerging pedagogies]. Tendencias emergentes en educación con TIC, 13-32.

Akçayır, G., \& Akçayır, M. (2018). The flipped classroom: A review of its advantages and challenges. Computers \& Education, 126, 334-345. https://doi.org/10.1016/j.compedu.2018.07.021

Alkoudmani, R. M., \& Elkalmi, R. M. (2015). Challenges to web-based learning in pharmacy education in Arabic language speaking countries. Archives of Pharmacy Practice, 6(3), 41-47. http://www.archivepp.com/storage/models/article/AiW9kOAWCAy3B0PW06OB-

FsLnM3wLDMk6XGjwhoKScx2BUX3gVcm3hjSgH3ex/challenges-to-webbased-learning-in-pharmacyeducation-in-arabic-language-speaking-countries.pdf9

Almasseri, M., \& AlHojailan, M. I. (2019). How flipped learning based on the cognitive theory of multimedia learning affects students' academic achievements. Journal of Computer Assisted Learning. https://onlinelibrary.wiley.com/doi/abs/10.1111/ical.12386

Andone, D., \& Mihaescu, V. (2018). Blending MOOCS into higher education courses - A case study. In Proceedings of 2018 Learning with MOOCS (LWMOOCS), 134-136. https://doi.org/10.1109/lwmoocs.2018.8534606

Ayçiçek, B., \& Yanpar Yelken, T. (2018). The effect of flipped classroom model on students' classroom engagement in teaching English. International Journal of Instruction, 11(2), 385-398. https://doi.org/10.12973/iji.2018.11226a

Berenguer-Albaladejo, C. (2016). Acerca de la utilidad del aula invertida o flipped classroom. [About the usefulness of the flipped classroom]. University of Alicante, Instituto de Ciencias de la Educación.

Bhagat, K. K., Chang, C.-N., \& Chang, C.-Y. (2016). The impact of the flipped classroom on mathematics concept learning in high school. Journal of Educational Technology \& Society, 19(3), 134-142.

Bishop, J. L., \& Verleger, M. A (2013). The flipped classroom: A survey of the research. ASEE national conference proceedings, Atlanta, GA, 1-18. 
Bissoli, A. C. F., dos Santos, G. A., \& Conde, S. J. (2018). Learning material design for teaching genetics while implementing flipped classroom. Revista Ibero-americana de Estudos em Educacao, 13(1), 468-478. https://doi.org/10.21723/riaee.nesp1.v13.2018.11440

Cabero Almenara, J. (2015). Reflexiones educativas sobre las tecnologías de la información \& la comunicación [Educational reflections on information \& communication technologies]. Tecnología, Ciencia y Educación, 1927.

Cheng, G., \& Ng, W. S. (2019). Secondary students' views on using flipped classroom to learn computer programming: Lessons learned in a mixed methods study. In International Conference on Technology in Education, 27-36. Guangzhou, China, March 15-17. https://doi.org/10.1007/978-981-13-9895-7 3

Cheng, L., Ritzhaupt, A. D., \& Antonenko, P. (2019). Effects of the flipped classroom instructional strategy on students' learning outcomes: A meta-analysis. Educational Technology Research and Development, 67(4), $793-824$. https://doi.org/10.1007/s11423-018-9633-7

Churches, A. (2009). Taxonomía de Bloom para la era digital [Bloom’s taxonomy for the digital age]. Eduteka. Recuperado, 11.

Conklin, J. (2005). Book Review: A taxonomy for learning, teaching, and assessing: A revision of Bloom's taxonomy of educational objectives complete edition. Educational Horizons, 83(3), 154-159. https://www.jstor.org/stable/42926529?seq=1

Davies, R. S., Dean, D. L., \& Ball, N. (2013). Flipping the classroom and instructional technology integration in a college-level information systems spreadsheet course. Educational Technology Research and Development, 61(4), 563-580. https://doi.org/10.1007/s11423-013-9305-6

Dawood, R., Syaryadhi, M., \& Irhamsyah, M. (2017). Measuring the increase in students' comprehension in a flipped introductory calculus course. International Conference on Interactive Collaborative Learning, 202-207. https://doi.org/10.1007/978-3-319-73210-7 24

de Araujo, Z., Otten, S., \& Birisci, S. (2017). Teacher-created videos in a flipped mathematics class: Digital curriculum materials or lesson enactments? ZDM, 49(5), 687-699. https://doi.org/10.1007/s11858-017$\underline{0872-6}$

Evangelista, I., Nardoni, F., \& Cadierno, M. (2018). Flipping the high-school classroom: Contributions for learning in a case study. In 2018 World Engineering Education Forum-Global Engineering Deans Council (WEEF-GEDC), 1-5. https://doi.org/10.1109/weef-gedc.2018.8629637

Fautch, J. M. (2015). The flipped classroom for teaching organic chemistry in small classes: Is it effective? Chemistry Education Research and Practice, 16(1), 179-186. https://doi.org/10.1039/c4rp00230j

Flumerfelt, S., \& Green, G. (2013). Using lean in the flipped classroom for at risk students. Journal of Educational Technology \& Society, 16(1), 356-366.

Fung, F. M. (2015). Using first-person perspective filming techniques for a chemistry laboratory demonstration to facilitate a flipped pre-lab. Journal of Chemical Education, 92(9), 1518-1521. https://doi.org/10.1021/ed5009624

García, I., Lemus, N., \& Toledo Morales, P. (2015). The flipped classroom through the smartphone: Effects of its experimentation in high school physical education. Prisma Social, 15, 296-352.

Giglio, A. (2014). Flipping classroom: Some experiments with university and k- 12 classes. In 6th International Conference on Education and New Learning Technologies (edulearn2014), 6406-6413.

Grella, C. T., Staubitz, T., Teusner, R., \& Meinel, C. (2016). Can MOOCS support secondary education in computer science? In International Conference on Interactive Collaborative Learning, 478-493. https://doi.org/10.1007/978-3-319-50337-0 45

Hao, Y. (2016). Middle school students' flipped learning readiness in foreign language classrooms: Exploring its relationship with personal characteristics and individual circumstances. Computers in Human Behavior, 59, 295-303. https://doi.org/10.1016/j.chb.2016.01.031 
Flipped Classroom Model: Technological Tools

Hodgson, T. R., Cunningham, A., McGee, D., Kinne, L., \& Murphy, T. J. (2017). Assessing behavioral engagement in flipped and non-flipped mathematics classrooms: Teacher abilities and other potential factors. International Journal of Education in Mathematics Science and Technology, 5(4), 248-261. https://doi.org/10.18404/ijemst.296538

Huang, Y.-N., \& Hong, Z.-R. (2016). The effects of a flipped English classroom intervention on students' information and communication technology and English reading comprehension. Educational Technology Research and Development, 64(2), 175-193. https://doi.org/10.1007/s11423-015-9412-7

Jiugen, Y., Ruonan, X., \& Wenting, Z. (2014). Essence of flipped classroom teaching model and influence on traditional teaching. 2014 IEEE Workshop on Electronics, Computer and Applications, 362-365. https://doi.org/10.1109/iweca.2014.6845632

Kashada, A., Li, H., \& Su, C. (2017). Adoption of flipped classrooms in k-12 education in developing countries: Challenges and obstacles. International Journal of Emerging Tecbnologies in Learning (iJET), 12(10), 147-157. https://doi.org/10.3991/ijet.v12i10.7308

Kim, M. K., Kim, S. M., Khera, O., \& Getman, J. (2014). The experience of three flipped classrooms in an urban university: An exploration of design principles. The Internet and Higher Education, 22, 37-50. https://doi.org/10.1016/j.iheduc.2014.04.003

Kong, S. C. (2014). Developing information literacy and critical thinking skills through domain knowledge learning in digital classrooms: An experience of practicing flipped classroom strategy. Computers \& Education, 78, 160-173. https://doi.org/10.1016/i.compedu.2014.05.009

Kong, S. C. (2015). An experience of a three-year study on the development of critical thinking skills in flipped secondary classrooms with pedagogical and technological support. Computers \& Education, 89, 16-31. https://doi.org/10.1016/i.compedu.2015.08.017

Kostaris, C., Stylianos, S., Sampson, D. G., Giannakos, M., \& Pelliccione, L. (2017). Investigating the potential of the flipped classroom model in k-12 ICT teaching and learning: An action research study. Journal of Educational Technology \& Society, 20(1), 261-273. https://www.jstor.org/stable/pdf/jeductechsoci.20.1.261.pdf?seq $=1$

Lage, M. J., Platt, G. J., \& Treglia, M. (2000). Inverting the classroom: A gate- way to creating an inclusive learning environment. The Journal of Economic Education, 31(1), 30-43. https://doi.org/10.1080/00220480009596759

Leo, J., \& Puzio, K. (2016). Flipped instruction in a high school science classroom. Journal of Science Education and Technology, 25(5), 775-781. https://doi.org/10.1007/s10956-016-9634-4

$\mathrm{Li}, \mathrm{Y}$. (2015). Application of flipped classroom on the sports dance teaching in colleges and universities - Taking routine creation as an example. The Open Cybernetics \& Systemic Journal, 9(1). https://doi.org/10.2174/1874110x01509011796

Li, Y., \& Daher, T. (2016). Integrating innovative classroom activities with flipped teaching in a water resources engineering class. Journal of Professional Issues in Engineering Education and Practice, 143(1), 05016008. https://doi.org/10.1061/(ASCE)EI.1943-5541.0000297

Li, Y., Luo, W., \& Zhao, X. (2018). Flipped classroom teaching model for engineering education based on CDIO. 2018 13th International Conference on Computer Science Education (ICCSE), 1-4. https://doi.org/10.1109/iccse.2018.8468707

Li, Z., Qian, J., \& Gao, S. (2017). Research on the application of flipped classroom model in English teaching. In Proceedings of the International Conference on Digital Technology in Education (pp. 49-53).

Linares-Espinós, E., Hernández, V., Domínguez-Escrig, J.L. Fernández-Pello,S., \& Hevia, V. (2018). Metodología de una revisión sistemática [Methodology of a systematic review]. Actas Urológicas Españolas, 42(8),499-506. https://doi.org/10.1016/i.acuro.2018.01.010

Lo, C. K., \& Hew, K. F. (2018). A comparison of flipped learning with gamification, traditional learning, and online independent study: The effects on students' mathematics achievement and cognitive engagement. Interactive Learning Environments, 1-18. https://doi.org/10.1080/10494820.2018.1541910 
Lo, C. K., Hew, K. F., \& Chen, G. (2017). Toward a set of design principles for mathematics flipped classrooms: A synthesis of research in mathematics education. Educational Research Review, 22, 50-73. https://doi.org/10.1016/i.edurev.2017.08.002

Lo, C. K., Lie, C. W., \& Hew, K. F. (2018). Applying "first principles of instruction" as a design theory of the flipped classroom: Findings from a collective study of four secondary school subjects. Computers \& Education, 118, 150-165. https://doi.org/10.1016/j.compedu.2017.12.003

Martínez, D. R., Merino, P. J. M., Valiente, J. A. R., Kloos, C. D., Díaz, H. J. P., \& Ruiz, J. S. (2015). Combining learning analytics and the flipped classroom in a MOOC of maths. In EC-TEL 2015 Workshops CHANGEE, W APLA, and HybridEd, 71-79. http://ceur-ws.org/Vol-1599/9WAPLA 2015.pdf

Martínez-Olvera, W., \& Esquivel-Gámez, I. (2018). Uso del modelo de aprendizaje invertido en un bachillerato público [Using the flipped learning model in a public high schoo]. Revista de Educación a Distancia, 58, Article 11. https://doi.org/10.6018/red/58/11

Martínez Olvera, W., Esquivel-Gámez, I., \& Martínez Castillo, J. (2014). Aula invertida o modelo invertido de aprendizaje: Origen, sustento e implicaciones [Inverted classroom or inverted learning model: Origin, livelihood, and implications]. Los Modelos Tecno-Educativos, revolucionando el aprendizaje del siglo, XXI, 143-160.

Mason, G. S., Shuman, T. R., \& Cook, K. E. (2013). Comparing the effectiveness of an inverted classroom to a traditional classroom in an upper-division engineering course. IEEE Transactions on Education, 56(4), 430435. https://doi.org/10.1109/te.2013.2249066

McBride, C. (2015). Flipping advice for beginners: What I learned flipping undergraduate mathematics and statistics classes. Primus, 25(8), 694-712. https://doi.org/10.1080/10511970.2015.1031300

Méndez, P. J. (2012). Mundos cambiantes: La tecnología \& la educación 3.0 [Changing worlds: Technology and education 3.0]. Revista Complutense de Educación, 23(1), 11-22. https://doi.org/10.5209/rev rced.2012.v23.n1.39099

Overmyer, J. (2015). Research on flipping college algebra: Lessons learned and practical advice for flipping multiple sections. Primus, 25(9-10), 792-802. https://doi.org/10.1080/10511970.2015.1045572

Palazón, J., \& Giráldez, A. (2018). QR codes for instrumental performance in the music classroom. International Journal of Music Education, 36(3), 447-459. https://doi.org/10.1177/0255761418771992

Palazón-Herrera, J. (2018). Effectiveness and motivation towards the use of video tutorials when learning how to use music software/efectividad \& motivación hacia el uso de videotutoriales para el aprendizaje de un software musical. Cultura \& Educación, 30(4), 663-692. https://doi.org/10.1080/11356405.2018.1514804

Pereira, I., \& Figueiredo, A. D. (2010). Promoting motivation and participation in higher education: A b-learning experience. 2010 IEEE Frontiers in Education Conference (FIE), S1C-1-S1C-6. https://doi.org/10.1109/fie.2010.5673204

Peres, P., Oliveira, L., Jesus, \& Silva, A. (2017). Designing learning paths: Contributions to the organization of b-learning initiatives. 2017 12th Iberian Conference on Information Systems and Technologies (CISTI), 1-6. https://doi.org/10.23919/cisti.2017.7975727

Rahman, A. A., Zaid, N. M., Abdullah, Z., Mohamed, H., \& Aris, B. (2018). Evaluation of students' dependency on out-of-class learning: A flipped classroom approach. In 2018 IEEE International Conference on Teaching, Assessment, and Learning for Engineering (TALE) (pp. 1172-1175). https://doi.org/10.1109/tale.2018.8615263

Ruiz-Rosero, J., Ramirez-Gonzalez, G., \& Viveros-Delgado, J. (2019). Software survey: ScientoPy, a scientometric tool for topics trend analysis in scientific publications. Scientometrics, 1-24. https://doi.org/10.1007/s11192-019-03213-w

Schultz, D., Duffield, S., Rasmussen, S. C., \& Wageman, J. (2014). Effects of the flipped classroom model on student performance for advanced placement high school chemistry students. Journal of Chemical Education, 91(9), 1334-1339. https://doi.org/10.1021/ed400868x

Shao, H., Du, D., \& Cui, S. (2016). Application of "flipped classroom in China's colleges and universities. In 2016 3rd International Conference on Management, Education Technology and Sports Science (METSS 2016), 489-491. https://doi.org/10.2991/metss-16.2016.100 
Flipped Classroom Model: Technological Tools

Slemmons, K., Anyanwu, K., Hames, J., Grabski, D., Mlsna, J., Simkins, E., \& Cook, P. (2018). The impact of video length on learning in a middle-level flipped science setting: Implications for diversity inclusion. Journal of Science Education and Technology, 27(5), 469-479. https://doi.org/10.1007/s10956-018-9736-2

Soares, F., \& Lopes, A. P. (2016). Teaching mathematics using massive open online courses. Proceedings of INTED2016 Conference 7th-9th March 2016, 2635-2641. https://doi.org/10.21125/inted.2016.1563

Sosa, O. G., \& Manzuoli, C. H. (2019). Models for the pedagogical integration of information and communication technologies: A literature review. Ensaio: Avaliacao e Politicas Públicas em Educacao, 27(102), 129-156. https://doi.org/10.1590/s0104-40362018002701720

Sotelo, F., Ordóñez, A., \& Solarte, M. F. (2015). Marco de referencia para la integración de recursos web como servicios de e-learning en .LRN [Reference framework for integrating web resources as e-learning services in .LRN]. Tecnura, 16(46), 79-92. https://doi.org/10.14483/udistrital.jour.tecnura.2015.4.a06

Takemata, K., Kodaka, A., Minamide, A., \& Nakamura, S. (2013). Engineering project-based learning under the CDIO concept. Proceedings of 2013 IEEE International Conference on Teaching, Assessment and Learning for Engineering (TALE), 258-261. https://doi.org/10.1109/tale.2013.6654442

Triantafyllou, E., Timcenko, O., \& Busk Kofoed, L. (2015). Student behaviors and perceptions in a flipped classroom: A case in undergraduate mathematics. Proceedings of the Annual Conference of the European Society for Engineering Education 2015 (SEFI 2015).

UNDP. (2018). Human development indices and indicators: 2018 statistical update. United Nations Development Programme New York.

Ureña, M. G., Gómez, L. M., Ruiz, V. V., Calderón, E., Crispín, A. L., González, M. Á. F., \& Gallego, J. V. (2007). Computer Aided Learning in Medicine \& Surgery Teaching at Medical School. Cirugía Andalura 2007, 18 (9-14). http://asacirujanos.com/admin/upfiles/revista/2007/2007-vol18-n1-act1.pdf

Wang, Y. (2016). A pilot evaluation of the Chinese learning system to support a flipped classroom. 2016 IEEE 16th International Conference on Advanced Learning Technologies (ICALT), 319-323. https://doi.org/10.1109/icalt.2016.1

Winter, J. W. (2018). Performance and motivation in a middle school flipped learning course. TechTrends, 62(2), 176-183. https://doi.org/10.1007/s11528-017-0228-7

Yan, O.-S., \& Cheng, G. (2017). Exploring the impact of flipped classroom on students' acceptance of programming in secondary education. In 2017 IEEE 6th International Conference on Teaching, Assessment, and Learning for Engineering (TALE) (pp. 246-249). https://doi.org/10.1109/tale.2017.8252341

Yang, C. C. R. (2017). An investigation of the use of the flipped classroom pedagogy in secondary English language classrooms. Journal of Information Technology Education: Innovations in Practice, 16(1), 1-20. https://doi.org/10.28945/3635

Ye, S.-H., Hsiao, T.-Y., \& Sun, C.-T. (2018). Using commercial video games in flipped classrooms to support physical concept construction. Journal of Computer Assisted Learning, 34(5), 602-614. https://doi.org/10.1111/jcal.12267

Yildiz Durak, H. (2018). Flipped learning readiness in teaching programming in middle schools: Modelling its relation to various variables. Journal of Computer Assisted Learning, 34(6), 939-959. https://doi.org/10.1111/jcal.12302

Zhao, L., \& Gao, X. (2010). A study of blended-learning in vocational college under the network environment a case study of" network marketing course. 2010 2nd International Symposium on Information Engineering and Electronic Commerce, 1-4. https://doi.org/10.1109/ieec.2010.5533208

Zheng, L. (2016). Application research on "flipped classroom" teaching mode in colleges and universities. In International Conference on Education, Management and Computing Technology (ICEMCT-16), 1213-1218. https://doi.org/10.2991/icemct-16.2016.258 


\section{BIOGRAPHIES}

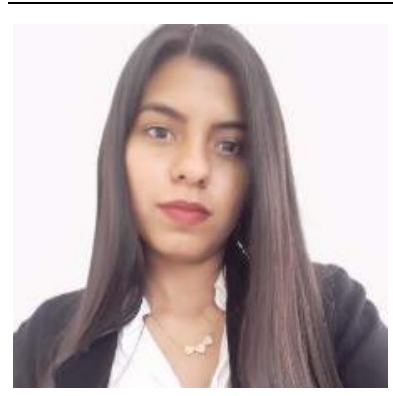

Lina M. Pastes Urbano. Electronic and Telecommunications Engineering Student (University of Cauca-Colombia). She is a collaborating member of the research seedbed Libero of the FUP (Fundación Universitaria de Popayán); His main research interests, including virtual educational environments, flipped classroom, blended learning, learning analysis, and computer science

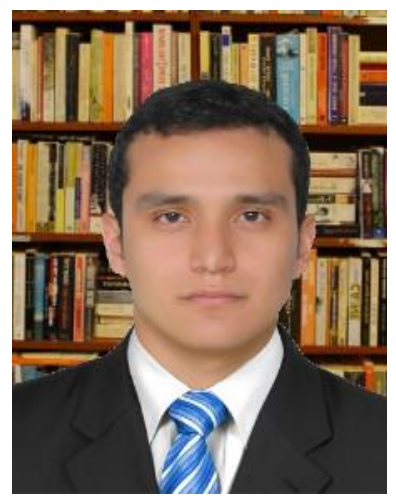

Hamil S. Terán. Electronic and Telecommunications Engineering Student (University of Cauca-Colombia), currently he is a global member of the Internet Society, also member of the Spanish chapter of the Internet Society (ISOC-ES) and collaborating member of the chapter IEEE AESS Unicauca (University of Cauca). His research interests include virtual educational environments, flipped classroom, blended learning, learning analysis, and computer science.

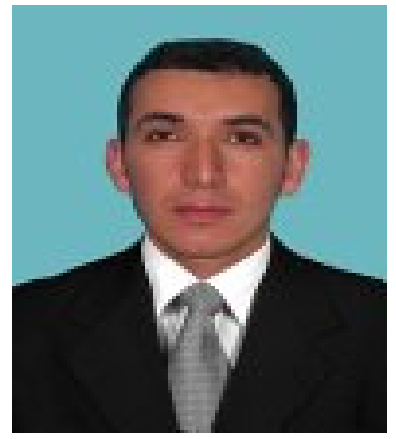

Fabinton Sotelo Gómez. Received his master's degree in telematic engineering from the Universidad del Cauca since 2013 and a systems engineer from the Universidad Nacional Abierta \& Distancia (UNAD), he is currently director of the research seedbed LÍBERO and a doctoral candidate in the telematic engineering department of the Universidad del Cauca. His research interests focus on massive online courses, e-learning, blended learning, and flipped classroom.

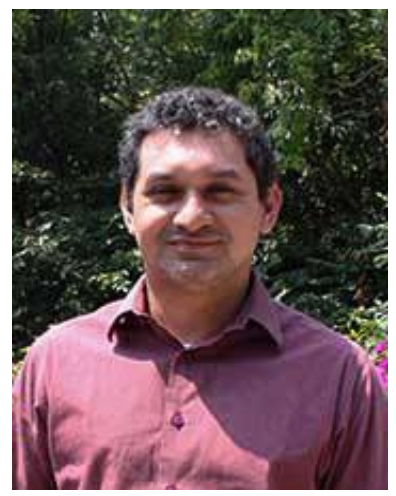

Mario F. Solarte. Received his $\mathrm{PhD}$ in telematic engineering from University of Cauca since 2019. MSc in Telematic Engineering since 2009. Specialist in formulation and evaluation of social development projects, from the Iberoamerican University Corporation in 2000 and electronics and telecommunications engineer from the University of Cauca. He currently works as a researcher and professor in the telematic engineering department of the University of Cauca, and collaborates in various research projects. His research interests focus on Elearning, Massive Online Courses, Learning Styles and Digital Education Contents. 


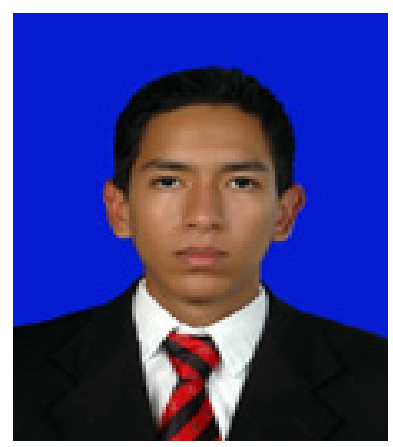

Carlos J. Sepulveda. Electronic and Telecommunications Engineering Student (University of Cauca - Colombia). He is a collaborating member of the research seedbed Líbero of the FUP (Fundación Universitaria de Popayán). His research interests include flipped classroom, use of ICT in education and computer science

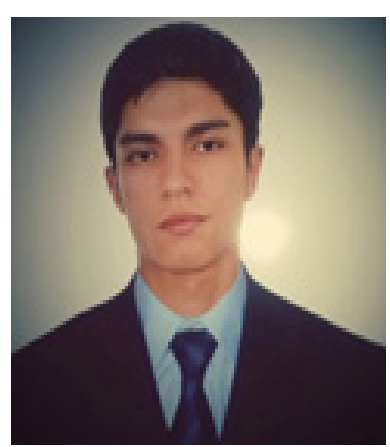

Juan M. López Meza. Electronic Engineering and Telecommunications student (University of Cauca-Colombia). Collaborating member of the LÍBERO research group attached to the Popayán University Foundation. His research interests include ICT use in education 